\title{
The Desert Laboratory Repeat Photography Collection-An Invaluable Archive Documenting Landscape Change
}

he Desert Laboratory Repeat
Photography Collection, the
largest collection of its kind in the
world, is housed at the U.S. Geo-
logical Survey (USGS) in Tucson,
Arizona. The collection preserves
thousands of photos taken pre-
cisely in the same places but at
different times. This archive of
"repeat photographs" documents
changes in the desert landscape
and vegetation of the American
Southwest, and also includes
images from northwestern Mexico
and Kenya. These images
are an invaluable asset to help
understand the effects of climate
variation and land-use practices on
arid and semiarid environments.

The U.S. Geological Survey

(USGS) is the guardian of the largest archive of "repeat photographs" in the world-the Desert Laboratory Collection-which contains images not only from the American Southwest, but also from northwestern Mexico and Kenya. Repeat photographs are used to document landscape changes over time and are taken at precisely the same locations at specific sites at different times.

\section{History of Repeat Photography and the Desert Laboratory Collection}

The Desert Laboratory Repeat Photography Collection is rooted in the work of a Bavarian professor, Sebastian Finsterwalder, who pioneered the technique of repeat photography. Beginning in 1889, Finsterwalder compared older and newer photographs he had taken of mountain glaciers to estimate rates of glacial retreat (melting) in the Alps. Before the 1950 s, only a few studies used repeat photography as a scientific tool in the United States. In 19561957, Homer Shantz repeated images he had taken on 1919-20 and 1924 excursions from Cape Town to Cairo in Africa (Shantz and Turner, 1958). This publication, the first book-length report of landscape change relying entirely on repeat photography, was highly influential in the fledgling field.

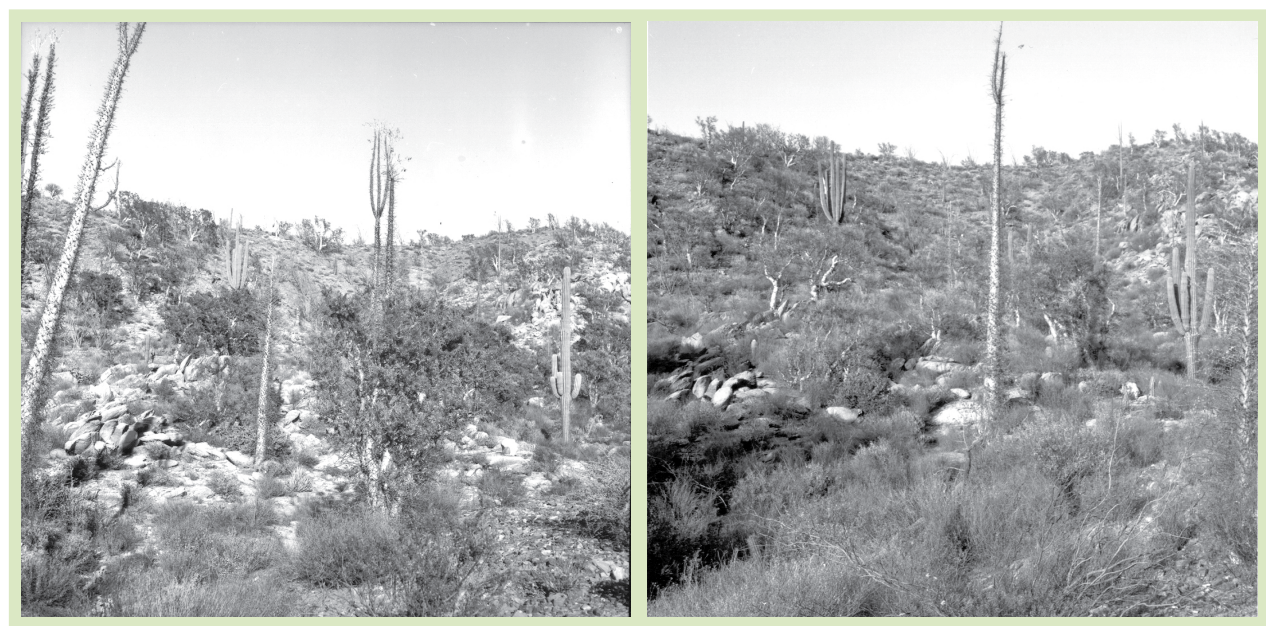

These repeat photographs document vegetation change on a hillside in Baja California. The left view taken in 1966 shows cirio (center) and cardón (left and right midground), as well as other woody plant species typical of this desert region. The right image taken in 1996 documents the relative growth rates and life spans of cirio and cardón. The cirio at center has doubled in size, and the individual directly behind it in 1966 is now dead. Both cardón remain alive and have grown more slowly than the cirio in the intervening 30 years.

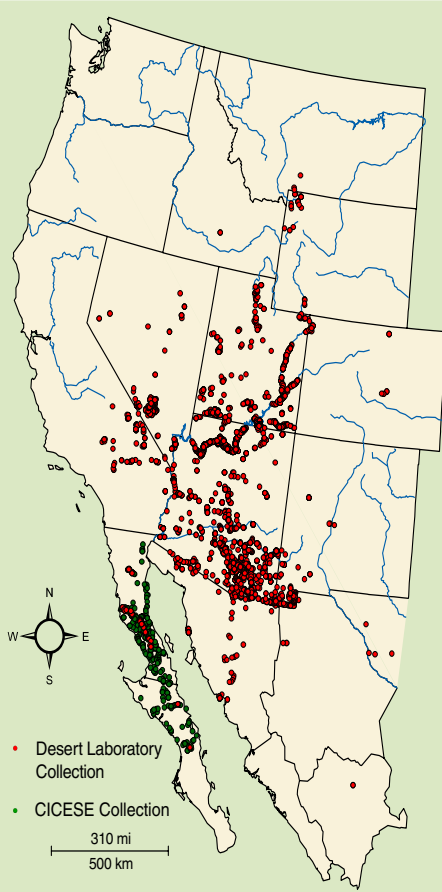

Map of the western United States and Mexico showing the locations of camera stations used by the Desert Laboratory Repeat Photography Collection and Centro de Investigación Científica y de Educación Superior de Ensenada (CICESE) in collaboration with USGS scientists. The five regions with the most photographic matches are northern Arizona (1,904 stations), southern Arizona (1,904 stations), southern Utah (902 stations), Baja California (636 stations), and southern Nevada (467 stations).

In the late 1950s, Jim MacDonald from the University of Arizona in Tucson wanted to analyze vegetation change documented in repeat photographs as a proxy for climatological data. McDonald recruited James Rodney Hastings to conduct field work on repeat photography of the Sonoran Desert. Hastings's project gained the attention of Raymond M. Turner, and in the summer of 1960, they began a long collaboration to systematically replicate historical photographs of the region. This effort culminated in the classic book The Changing Mile (Hastings and Turner, 1965), which documents long-term vegetation change in the vertical mile of elevation that encompasses the Sonoran Desert. This book was recently updated as The 

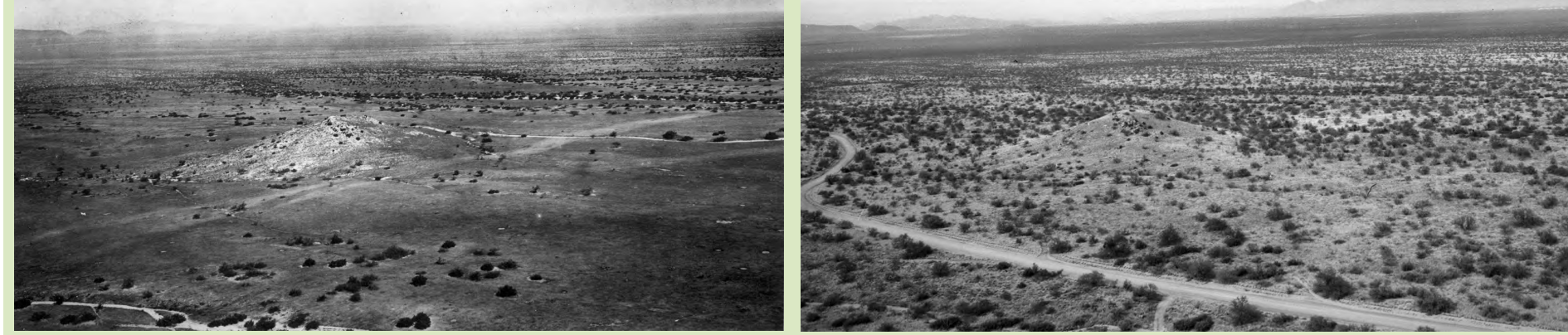

Repeat photographs looking to the northwest from the summit of Huérfano Butte on the Santa Rita Experimental Range south of Tucson, Arizona, showing vegetation and landscape changes. The left view to the northwest taken in 1902 shows a desert grassland with desert hackberry as the dominant woody plant, and velvet mesquite are few and widely scattered. The right photo taken in 1986 shows that the formerly open grassland is now a thorn-scrub savanna following the large increase of mesquite, whereas the abundance of hackberry remains essentially unchanged, and most of the plants present in 1902 have persisted. Also note the new road in the 1986 image, showing the human influence on this landscape.

Changing Mile Revisited (Turner and others, 2003).

The Desert Laboratory Collection, established by Turner in 1960, greatly expanded as the applications for repeat photography increased. In the early 1980s, Robert Webb engaged Turner, by then a member of the USGS, to study ecosystem recovery at abandoned ghost towns in the Mojave Desert. In 1989, Turner retired from the USGS, and Webb became the guardian of the collection. Webb applied the repeat-photography technique to a wide variety of research questions ranging from long-term channel change of regional rivers-such as change along the Colorado River in Grand Canyon-to documentation of changes in permanent vegetation plots in the Mojave Desert. Turner, meanwhile, continued to use repeat photography in documenting the combined effects of climate variability and land-use practices, including an expansion of Shantz's work in Kenya (Turner and others, 1995). The collection now includes matches of photographs that date to the $1860 \mathrm{~s}$.

In the early 1960s, Hastings and Turner used repeat photography to help in studying the biogeography of desert plants in Baja California, Mexico. In the mid-1990s, Stephen Bullock of Centro de Investigación Científica y de Educación Superior de Ensenada (CICESE), a Mexican government agency in Ensenada, Baja California, asked Turner and Webb to help assess landscape change on the Baja Peninsula, focusing on long-term change in columnar succulent plant species affected by land-use practices. This ongoing work has shown systematic changes in the populations of highly valued plant species on the peninsula (Bullock and others, 2005).

As of 2007, the Desert Laboratory Collection contains about 35,000 negatives and transparencies taken at 4,961 camera stations. A total of 6,766 original photographs taken at these camera stations were used to create 9,658 matches (many images have been matched multiple times). The largest number of matches was made in Grand Canyon, the site of ongoing studies related to the effects of Glen Canyon Dam on the Colorado River (Webb, 1996). The southern and northern Arizona regions have the most matches $(1,904)$, followed by southern Utah (902). A total of 636 camera stations have been established in Baja California and another 150 in Kenya.

\section{Repeat Photography in Action- Some Examples}

\section{Understanding Long-term Change in the Central Desert of Baja California}

The 10-year collaboration in Baja California between USGS and CICESE focuses on quantifying rates and directions of change in plant populations and communities over the last century in the Vizcaíno Region of the Sonoran Desert. This effort documents long-term trends in mortality and "recruitment" of different plant species, and the growth rates and ages of two species - the columnar succulents cirio (Fouquieria columnaris) and cardón (Pachycereus pringlei) - that are emblematic of this region. Factors that may affect changes in plant communities and individual plants include plant harvesting, livestock grazing, off-road vehicle use, soil properties, climatic fluctuations, and geomorphic (land-shaping) processes, such as floods and stream-channel change. The project's long-term goal is to create and maintain a baseline photographic archive for the region by compiling historical data from many widely dispersed sources and adding data from new sites to fill some critical gaps in the coverage of amount and rate of landscape change.

\section{Tracking the Encroachment of Woody Vegetation in the Desert Grassland of Southern Arizona}

Historically, the desert grassland of southeastern Arizona and southwestern New Mexico was relatively free of woody vegetation (Turner and others, 2003). Two factors associated with European settlement changed this ecosystem-(1) fires set by lightning strikes or by Native Americans were actively suppressed, and (2) livestock consumed the fine fuels that formerly carried fires across the landscape. In addition, a climatic variation that favored increased winter rainfall during much of the past century encouraged woody species, notably native mesquite (Prosopis velutina and P. glandulosa) to expand their distribution from wash habitats to uplands. Repeat photos in the Desert Laboratory Collection continue to document these changes and the resulting disappearance of the once-open grassland and the establishment of a thornscrub 
savannah dominated by woody leguminous trees, particularly mesquite.

\section{Documenting Changes in Riparian Vegetation in the Southwestern United States}

Plant communities along river margins ("riparian" vegetation) in the southwestern United States are threatened by water development, particularly the excessive use of ground water. Repeat photographs in the Desert Laboratory Collection show that large changes in riparian vegetation have occurred throughout the region (Webb and others, 2007), ranging from total removal in areas where ground-water extraction is excessive to large increases in areas once either barren or too swampy to admit growth of woody species. Increases have occurred both in native and nonnative riparian vegetation. Nonnative tamarisk (Tamarix ramosissima) forms monospecific stands that appear to exclude native species along several river reaches, but the establishment of native stands dominated by cottonwood (Populus fremontii) has occurred along numerous smaller rivers in the region, notably the San Pedro River in southeastern Arizona (Webb and others, 2007).

Change in riparian vegetation is inextricably linked to both climatic and geomorphic processes. Opportunities for the establishment of woody riparian vegetation followed down-cutting of arroyos in the late $19^{\text {th }}$ and early $20^{\text {th }}$ centuries that drained waterlogged floodplains. Periods of high winter rainfall during the early and late $20^{\text {th }}$ century led to large winter floods, which simultaneously eliminated riparian vegetation and promoted germination and establishment of native and non-native species. Establishment of woody vegetation within arroyo walls promotes sedimentation on low floodplains, which promotes additional vegetation growth.
These photographs of the Escalante River at Escalante, Utah, document the interaction of riparian vegetation and channel morphology, which could lead to sediment accumulation and the filling of arroyos. The top view, taken shortly after an extremely large flood damaged the town of Escalante in 1932, shows a wide river channel devoid of riparian vegetation. The bed of this arroyo is several meters below the top of its former floodplain following the downcutting associated with another large flood in 1909. Fifty-three years later (middle image), riparian vegetation, mostly non-native tamarisk and Russian olive, has encroached on the once barren channel. Native coyote willow may be present along the channel in the center distance. By 1999 (bottom image), dense riparian vegetation, a combination of cottonwood and non-native tamarisk and Russian olive, block the view of the background cliffs. The channel has narrowed considerably because the dense vegetation trapped sediments that developed into floodplain terraces. (Top photo courtesy of Utah State Historical Society.)

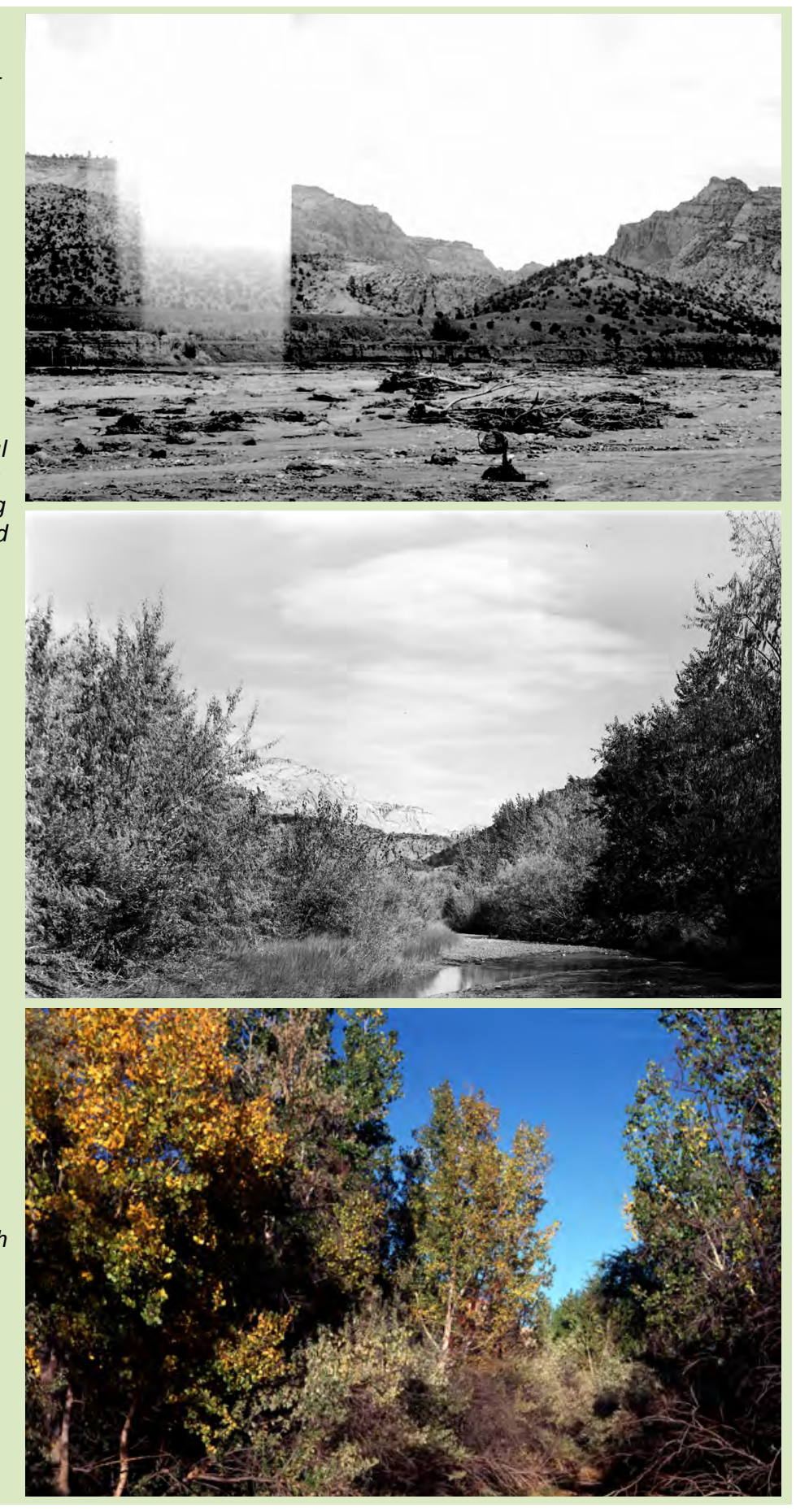

\section{Estimating Debris-flow Frequency}

Debris flows are a type of flash flood that occur periodically in the tributaries of the Colorado River in Grand Canyon and elsewhere in the region. They transport large boulders into the Colorado River and its tributaries, creating constrictions and rapids. The resulting interaction between debris flows and the river strongly influences the geomorphology. Because few tributaries are measured for flow and the region is so remote, knowledge of when debris flows occurred in the past and their effect on the river was not well known. Using repeat photography, Griffiths and others (2004) determined that on average five debris flows occur every year, based on occurrence at 160 tributaries in Grand Canyon (about $20 \%$ of the total number). They used the repeat-photography information as the basis of a statistical model of debris-flow frequency in Grand Canyon by comparing the tributaries that produced debris flows versus those that did not over a 100 -year period. 

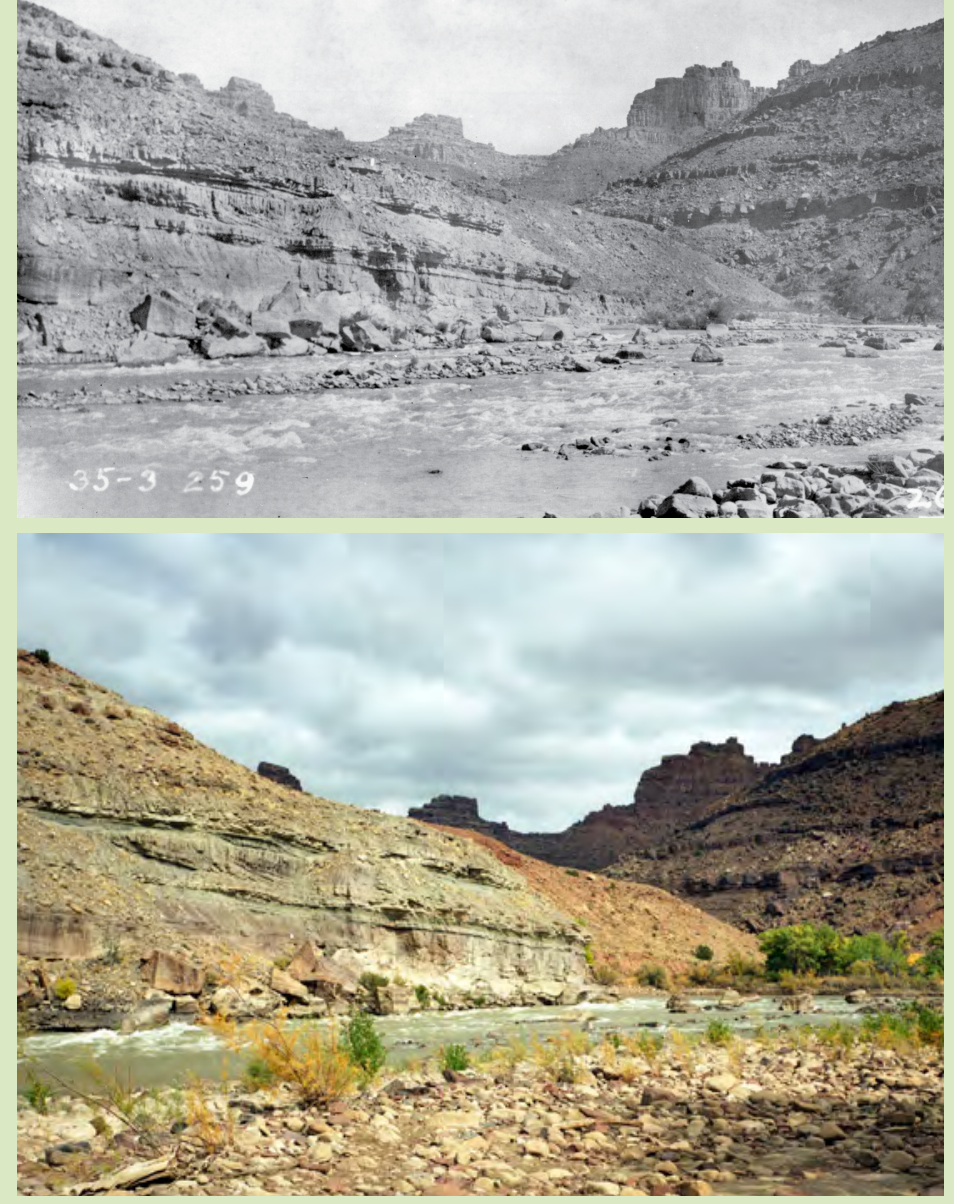

\section{The Role of USGS}

The invaluable archive of repeat photographs maintained by the Desert Laboratory Collection provides data that is crucial to helping understand the effects of climate variation and land-use practices on desert environments. Serving as the guardian and repository of this collection is only one of the many important scientific roles that the USGS is playing to help administer lands under the protection of the Department of the Interior and other government agencies.

Robert H. Webb, Diane E. Boyer, Raymond M. Turner, and Stephen $H$. Bullock

\section{References}

Bullock, S.H., Martijena, N.E., Webb, R.H., and Turner, R.M., 2005, Twentieth century demographic changes in cirio and cardón in Baja California: Journal of Biogeography, v. 32, p. 127-143.
Views of Three Fords Rapid on the Green River in Desolation Canyon, Utah.

The river, which is flowing right to left, is relatively wide and split into two channels in a photo taken in 1909 (top image). At some time in the intervening 89 years before the bottom image was taken, a debris flow from Three Fords Canyon East (behind the photographer to the right) deposited sediment into the Green River, greatly reducing the width of Three Fords Rapid. (Top photo courtesy of Northern Arizona University Cline Library.)

Griffiths, P.G., Webb, R.H., and Melis, T.S., 2004, Initiation and frequency of debris flows in Grand Canyon, Arizona: Journal of Geophysical Research, Surface Processes, v. 109 F04002, doi:10.1029/2003JF000077, $14 \mathrm{p}$.

Shantz, H.L., and Turner, B.L., 1958 Photographic documentation of vegetation changes in Africa over a third of a century: Tucson, University of Arizona, College of Agriculture, Report 169, 158 p.

Hastings, J.R., and Turner, R.M. , 1965, The changing mile: Tucson, University of Arizona Press, $317 \mathrm{p}$.

Turner, R.M., Ochung', H.A., and Turner, J.B., 1998, Kenya's changing landscape: Tucson, University of Arizona Press, $177 \mathrm{p}$.

Turner, R.M., Webb, R.H., Bowers, J.E., and Hastings, J.R., 2003, The changing mile revisited: Tucson, University of Arizona Press, 334 p.

Webb, R.H., 1996, Grand Canyon, a century of change: Tucson, University of Arizona Press, 290 p.

Webb, R.H., Leake, S.A., and Turner, R.M., 2007, The ribbon of greenChange in riparian vegetation in the Southwestern United States: Tucson, University of Arizona Press, 462 p.
Techniques and Storage of Repeat Photography Used by the Desert Laboratory Collection

Repeat photography techniques used to obtain matches of historical images:

- Tripod-mounted, large-format film cameras (4 by 5 inch sheet or 120 roll film) provide both high resolution and portability, yielding the best possible data.

- Film offers superior archival attributes to digital images; typically one color and two black-and-white negatives and one color transparency are made for each match.

- A variety of fixed lenses are used to approximately match the original field of view.

- Cameras used to take repeat photographs are leveled from side to side to allow more precise future replications.

- Whenever possible, repeat photos match the season, date, and even the time of day of the original photo.

- For each match, notes are taken-(1) camera model and its settings, (2) compass azimuth of the view, (3) camera's vertical tilt and height above ground level, and (4) view attributes, such as plant species, landforms, land-use practices, and any special considerations required to understand future changes.

- Originally, camera station locations were mapped on USGS topographic maps; now they are also documented using Global Positioning System (GPS) receivers.

Archival techniques:

- Negatives and transparencies are stored in archival plastic sleeves within archival, acid-free paper envelopes.

- A digital database includes a permanent "stake" number, assigned to each camera-station location, a brief description of the location, geospatial data, the name of the original photographer, the date of the original photograph, the archive from which the image was obtained and the accession number, and documentation of the number of matches and their dates.

- Matches are digitized using high-precision, large-format negative scanners and processed with software that allows manipulation of image size and quality.

- All media associated with camera stations are stored according to stake number.

\section{For more information, contact:}

Diane E. Boyer

U.S. Geological Survey

520 North Park Avenue, Suite 221

Tucson, Arizona, 85719-5035

Email: deboyer@usgs.gov

This Fact Sheet and any updates to it are available online at http://pubs.usgs.gov/fs/2007/3046/ 